\title{
ANALISA PERANCANGAN ALAT SIMULATOR GELOMBANG QRS SEBAGAI PENGENALAN POLA GELOMBANG ELEKTROKARDIOGRAF
}

\author{
Evrita Lusiana Utari \\ Jurusan Teknik Elektro, Fakultas Sains \& Teknologi Universitas Respati Yogyakarta \\ Jl. Laksda Adisucipto Km 6,3 Depok, Sleman, Yogyakarta 55281 Telp 0274489780 \\ E-mail : evrita_lusiana@yahoo.com
}

\begin{abstract}
Simulator machine of QRS wave has the input of PQRST as well as electrocardiograph wave parameter. The input of PQRST wave is tuned by setting the value of its amplitude and wavelength. The value is chosen based on the heart patients data that have been previously recorded. The validation value corresponds to the regulator value. Further, the validation value is compared to the short term electrocardiograph data that have been recorded for 5 minutes. The statistical and histogram based time domain analysis method are the two simplest analysis method of heart rate variation. The statistical analysis consists of two steps, i.e. the average and standard deviation of normal heart rate direct measurement. This measurement yields a negative deflection value of $Q$ from $R$ wave of 25\%, a positive deflective value of $R$ wave of 1.6-3 $\mathrm{mV}$, and a negative deflection of $S$ wave of $0.1-.5 \mathrm{mV}$.
\end{abstract}

Keywords : QRS Wave, EKG Detection, Simulator.

\section{PENDAHULUAN}

Penyakit jantung merupakan salah satu penyebab kematian terbesar di dunia dan di Indonesia. Sejumlah tokoh ditenggarai meninggal akibat serangan jantung. Untuk mengetahui kondisi kesehatan jantung biasanya digunakan alat elektrokardiografi (EKG). Di rumah sakit petugas medis dituntut memiliki kemampuan yang cukup dalam mengidentifikasi penyakit atau serangan jantung berdasarkan rekaman EKG. Namun pada kenyataannya banyak petugas medis tidak menguasai bagaimana cara membaca dan menginterprestasikan rekaman EKG. Banyak petugas paramedis beralasan bahwa membaca EKG adalah wewenang dokter atau dokter spesialis jantung.

Menyambut perkembangan teknologi yang semakin maju membuat manusia untuk selalu berusaha mengembangkan dan memanfaatkan teknologi tersebut untuk kemudahan dalam berbagai hal. Salah satu contoh adalah aplikasi perancangan simulator gelombang elektrokardiograf dengan penampil osiloskop sebagai alat pembelajaran. Berbicara soal jantung sangat erat hubungannya dengan alat elektrokardiograf (EKG), EKG adalah alat ukur yang digunakan untuk mengukur / mendeteksi kondisi jantung dengan cara memantau irama dan frekuensi detak jantung. Untuk mengukur detak jantung, elektrode - elektrode dari elektrokardiograf ditempatkan ke dada pasien. Elektrode mendeteksi turun - naiknya arus listrik jantung dan mengirimnya ke elektrokardiograf, yang merekam perubahannya sebagai bentuk gelombang pada gulungan kertas yang bergerak. Rekaman hasil pengukuran ini disebut elektrokardiogram. Setiap kontraksi, otot jantung menghasilkan impuls kelistrikan dalam bentuk gelombang sinusoidal (bentuk gelombang pada gerak harmonis) yang ditampilkan pada layar elektrokardiograf. untuk mempelajari sinyal EKG yang mempunyai parameter sinyal berupa gelombang $\mathrm{P}, \mathrm{Q}, \mathrm{R}, \mathrm{S}, \mathrm{T}$, dan U dibutuhkan suatu alat yang dapat menampilkan sinyal EKG. Akan tetapi alat tersebut cukup mahal dan penggunaannya cukup rumit, serta menghabiskan banyak waktu. Untuk itu, perlu dibuat perangkat dengan biaya terjangkau, mudah, praktis, fleksibel dan 
efisien dalam penggunaannya. Dalam merealisasikan perangkat tersebut diperlukan suatu alat simulator, organ utama dalam tubuh manusia salah satunya adalah jantung, jika terjadi kelainan kerja pada jantung akan berdampak pula pada aliran darah yang ke seluruh tubuh yang pada kategori tertentu bisa berakibat fatal. Terjadinya serangan penyakit jantung sebenarnya didahului dengan indikasi kelainan kerjanya yang bisa diamati dari ritme yang terjadi. Dengan menerapkan sistem peringatan adanya kelainan kerja jantung akan bisa diketahui secara cepat kondisi serta penanganannya. Untuk mendeteksi adanya kelainan kerja jantung maka harus diketahui terlebih dahulu ritme kerja jantung itu sendiri.

Sistem EKG standart terdiri dari 12 leads (I, II, III, aVR, aVL, aVF, V1, V2, V3, V4, V5 dan V6). Setiap lead mencatat aktivitas elektrik jantung dari posisi anatomi yang berbeda. Identitas dari perubahan miokardium pada lead tertentu dapat membantu menentukan kondisi patologis. Amplitudo normal dari gelombang $\mathrm{P}$ kurang lebih $3 \mathrm{~mm}$, durasi normal dari gelombang $\mathrm{P}$ adalah 0,04 - 0,11 detik. Gelombang $P$ yang lebih dari nilai ini diketahui adanya deviasi dari normal. Interval PR diukur dari naiknya gelombang $\mathrm{P}$ ke sambungan $\mathrm{QR}$ dan normalnya sekitar 0,12 dan 0,20 detik.

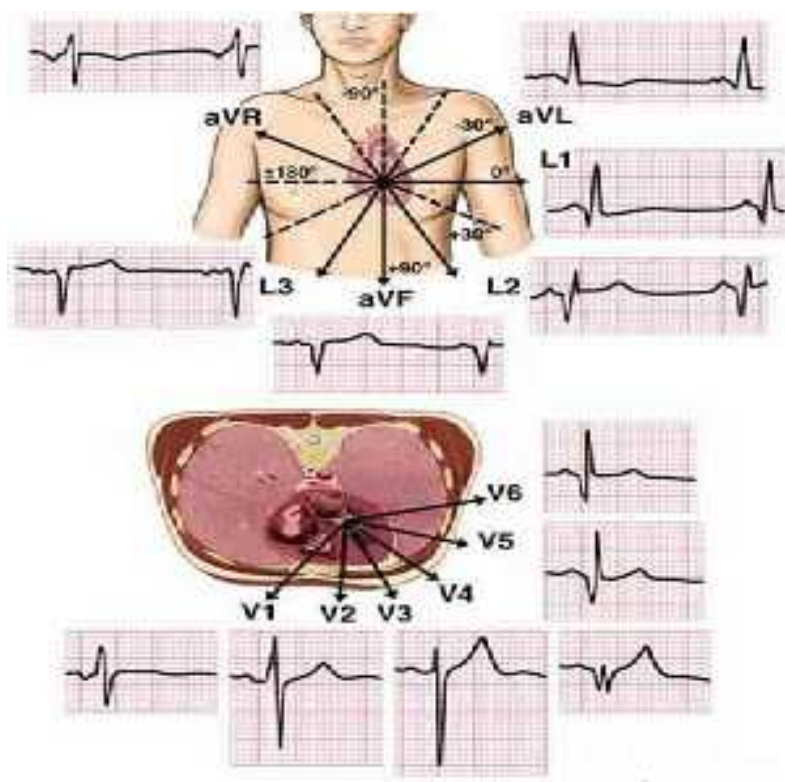

Gambar 1. Pola Gelombang Sinyal Kardiografi.
Interval PR merepresentasikan waktu transmisi impuls dari nodus SA ke nodus AV. Adanya kelambatan pada nodus AV untuk memungkinkan pengisian ventricular yang kuat untuk mempertahankan stoke volume yang normal (jumlah darah yang dikeluarkan setiap kontraksi). Kompleks QRS mengandung gelombang dan segmen yang berbeda, yang dapat dievalusi secara terpisah. Kompleks QRS normal berada pada range 0,06-0,10 detik.

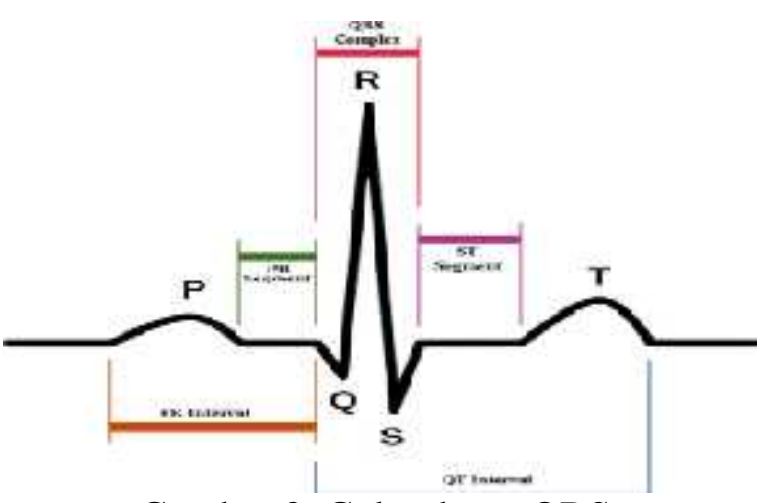

Gambar 2. Gelombang QRS.

Gelombang Q adalah penurunan pertama setelah gelombang $\mathrm{P}$, biasanya dalamnya kurang dari $3 \mathrm{~mm}$. Gelombang $\mathrm{Q}$ yang sangat defleksi merupakan keadaan yang tidak normal pada jantung yang sehat. Gelombang Q patologis biasanya mengidentifikasikan adanya old MI. Gelombang $\mathrm{R}$ merupakan defleksi positif pertama setelah gelombang $\mathrm{P}$, tinggi gelombang $\mathrm{P}$ pada kondisi normal adalah 5 $10 \mathrm{~mm}$. Peningkatan dan penurunan amplitudo menjadi sangat signifikan pada beberapa kondisi penyakit. Hipertrofi Ventrikular akan menimbulkan gelombang R yang sangat tinggi karena otot hipertrofi memerlukan arus listrik yang sangat kuat untuk depolarisasi. Segmen ST dimulai di akhir gelombang $\mathrm{S}$, merupakan defleksi negatif pertama setelah gelombang $\mathrm{R}$ dan berakhir pada peningkatan gelombang $\mathrm{T}$. Gelombang $\mathrm{T}$ harus selalu ada, dimana gelombang $\mathrm{T}$ tersebut merepresentasikan repolarisasi serabut miokardium atau keadaan istirahat dari kerja miokardium. Gelombang $\mathrm{T}$ normal tidak boleh istirahat lebih dari $5 \mathrm{~mm}$ pada semua lead, kecuali 
lead precordial (V1 sampai dengan V6 disini dapat istirahat lebih dari $10 \mathrm{~mm}$ ).

Elektrokardiograf merupakan alat bantu dokter untuk mengetahui aktivitas listrik jantung, yang merekam aktivitas kelistrikan jantung dalam waktu tertentu. Namanya terdiri atas sejumlah bagian yang berbeda: elektro, karena berkaitan dengan elektronika, kardio, kata Yunani untuk jantung, gram, sebuah akar Yunani yang berarti "menulis". Analisis sejumlah gelombang dan vektor normal depolarisasi dan repolarisasi menghasilkan informasi diagnostik yang penting. Adapun fungsi dari elektrokardiogram :

- Merupakan standar emas untuk diagnosis aritmia jantung

- EKG memandu tingkatan terapi dan risiko untuk pasien yang dicurigai ada infark otot jantung akut.

- EKG membantu menemukan gangguan elektrolit (misal. hiperkalemia dan hipokalemia).

- EKG memungkinkan penemuan abnormalitas konduksi (mis. blok cabang berkas kanan dan kiri)

- EKG digunakan sebagai alat tapis penyakit jantung iskemik selama uji stres jantung.

- EKG kadang - kadang berguna untuk mendeteksi penyakit bukan jantung (misal. emboli paru atau hipotermia).

- Monitor EKG modern memiliki banyak penyaring untuk pemrosesan sinyal. Yang paling umum adalah mode monitor dan mode diagnostik. Dalam mode monitor, penyaring berfrekuensi rendah (juga disebut penyaring bernilai tinggi karena sinyal di atas ambang batas bisa lewat) diatur baik pada $0,5 \mathrm{~Hz}$ maupun $1 \mathrm{~Hz}$ dan penyaring berfrekuensi tinggi (juga disebut penyaring bernilai rendah karena sinyal di bawah ambang batas bisa lewat) diatur pada $40 \mathrm{~Hz}$. Hal ini membatasi EKG untuk pemonitoran irama jantung rutin. Penyaring bernilai tinggi membantu mengurangi garis dasar yang menyimpang dan penyaring bernilai rendah membantu mengurangi bising saluran listrik 50 atau $60 \mathrm{~Hz}$ (frekuensi jaringan saluran listrik berbeda antara 50 dan $60 \mathrm{~Hz}$ di sejumlah negara). Dalam mode diagnostik, penyaring bernilai tinggi dipasang pada $0,05 \mathrm{~Hz}$, yang memungkinkan segmen ST yang akurat direkam. Penyaring bernilai rendah diatur pada 40, 100, atau $150 \mathrm{~Hz}$. Sebagai akibatnya, tampilan EKG mode monitor banyak tersaring daripada mode diagnostik, karena bandpassnya lebih sempit.

\section{TINJAUAN PUSTAKA}

Beberapa penelitian yang telah dilakukan dengan implementasi pedektesian gelombang QRS komplek pada sistem peringatan kelainan kerja jantung nernasis mikrokontroler oleh Hendriyawan (2012) dalam penelitian tersebut dengan mencari nilai lokal maksimal gelombang QRS komplek untuk mengukur jarak waktu antar singleton. Selanjutnya penelitian dengan menggunakan metode identifikasi sinyal kardiografi ditunjukkan dengan perkembangan pertama kali oleh Ranjith (2006) yang melakukan penelitian dengan frekuensi $150 \mathrm{~Hz}$. Penelitian tentang analisis gelombang elektrokardiografi dengan menggunakan gelombang - singkat mexican hat yang ditambahkan dengan metode filter bank, dilaporkan mempunyai sensitivitas sebesar $87,5 \%$. Penelitian selanjutnya dilakukan dengan menggabungan metode gelombang-singkat morlet dengan metode neuro fuzzy untuk mendeteksi sinyal elektrokardiogram normal yang dilaporkan mempunyai sensitivitas sebesar 87,8\% (Mehmet, 2007).

Metode pendeteksian sinyal elektrokardiografi tanpa menggunakan preprosesing adalah algoritma kupev. Algoritma kupev dilaporkan mempunyai sensitivitas sebesar 90\% (Darrington, 2009). Penelitian dengan menggunakan metode transformasi wavelet diskrit untuk mendeteksi sinyal elektrokardiografi normal dilaporkan mempunyai sensitivitas sebesar 96,2\% (Ubeyli, 2010). Pengenalan pola sinyal seismik dengan menggunakan wavelet pada aktivitas gunung berapi (Utari, 2013). 
Pengenalan signal EKG menggunakan dekomposisi paket wavelet dan $k$-means clustering (Rizal, 2008) pada penelitian tersebut dilakukan pengenalan kelainan penyakit jantung berdasarkan sinyal EKG dengan menggunakan dekomposisi wavelet. Sinyal tersebut didekomposisi hingga level 5 dengan tingkat akurasi 94,4\%.

Dengan alih ragam gelombang - singkat ini dimungkinkan pelokasian frekuensi-waktu. Metode Thresholding, bertujuan untuk membatasi dan menghilangkan bagian-bagian pada sinyal yang dianggap tidak banyak mengandung informasi penting. Dengan cara menentukan nilai parameter data, maka bagianbagian yang dibatasi tersebut dapat dianggap sebagai derau yang tercampur.

Pengenalan signal EKG menggunakan dekomposisi paket wavelet dan k-means clustering (Rizal, 2008) pada penelitian tersebut dilakukan pengenalan kelainan penyakit jantung berdasarkan sinyal EKG dengan menggunakan dekomposisi wavelet. Sinyal tersebut didekomposisi hingga level 5 dengan tingkat akurasi 94,4\%.

\section{METODOLOGI PENELITIAN \\ a. Persiapan Alat dan Bahan \\ b. Perancangan Alat \\ c. Pengujian Alat \\ d. Analisa Hasil Pengujian}

\section{HASIL DAN PEMBAHASAN}

\subsection{Teknik-Teknik Elektrokardiografi}

Terdapat tiga teknik yang digunakan dalam elektrokardiografi meliputi :

1. Standart clinical ECG ini menggunakan teknik 10 elektrode dengan 12 lead yang ditempatkan pada titik - titik tubuh tertentu. Teknik ini digunakan untuk menganalisa pasien.

2.Vectorcardiogram, teknik ini menggunakan tiga elektroda yang ditempatkan pada titik - titik tubuh tertentu. Teknik ini menggunakan pemodelan potensial tubuh vektor tiga dimensi dengan menggunakan sandapan baku bipolar (Einthoven).
Dari sini akan dihasilkan gambar grafis dari eksitansi jantung.

3.Monitoring ECG, teknik ini menggunakan 1 atau 2 elektroda yang ditempatkan pada titik-titik tubuh tertentu. Teknik ini digunakan untuk memonitor pasien dalam jangka panjang.

\subsection{Karakteristik dan Parameter Parameter dalam EKG}

Sinyal EKG terdiri dari gelombang $\mathrm{P}$, kompleks QRS, dan gelombang T digunakan untuk mendeteksi kelainan jantung atau aritmia. Urutan terjadinya sinyal EKG yang dapat menimbulkan gelombang P, kompleks QRS, dan gelombang $\mathrm{T}$ (dengan deskripsi yang terdapat dalam Tabel 1. Parameter EKG).

\subsection{Data Perancangan Alat}

Potensiometer adalah sebuah jenis resistor yang nilai tahanannya atau hambatannya (resistansi) dapat diubah atau diatur (adjustable). Potensiometer memiliki 3 terminal, 2 terminal terhubung ke kedua ujung elemen resistif, dan terminal ketiga terhubung ke kontak geser yang disebut wiper. Posisi wiper menentukan tegangan keluaran dari potensiometer. Berikut ini simbol dari potensiometer, simbol potensiometer dengan standar International Electrotechnical Commission (IEC) dan standar American National Standards Institute (ANSI) dapat dilihat pada Gambar 3 dan gambar 4.

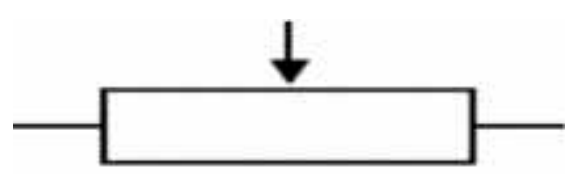

Gambar 3 Simbol Potensiometer Standar IEC.

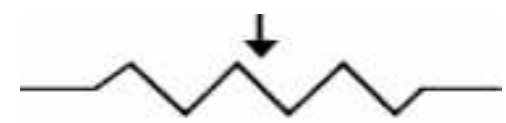

Gambar 4 Simbol Potensiometer Standar ANSI. 
Potensiometer pada dasarnya berfungsi sebagai pembagi tegangan variabel. Unsur resistif dapat dilihat sebagai dua resistor seri, dimana posisi wiper menentukan rasio resistensi dari resistor pertama ke resistor kedua. Potensiometer juga dikenal sebagai potmeter atau pot. Bentuk paling umum dari potmeter adalah potmeter putar. Jenis potmeter sering digunakan dalam kontrol volume suara audio dan berbagai aplikasi lainnya. Unsur resistif pada potensiometer biasanya terbuat dari bahan seperti karbon, keramik logam, gulungan kawat (wirewound), plastik konduktif, atau film logam.

\subsection{Op-Amp (Operational Amplifier)}

$O p$-Amp adalah suatu penguat gandengan langsung yang memperkuat sinyal arus searah (DC) atau tegangan yang berubah ubah terhadap satuan waktu. Penguatan yang tinggi dilengkapi dengan umpan balik untuk mengendalikan karakteristiknya secara menyeluruh. Simbol dari Op-Amp tampak pada gambar 5 .

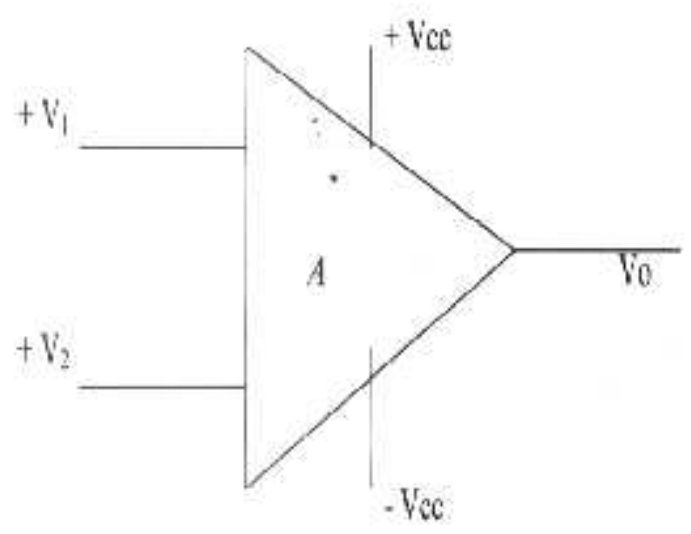

Gambar 5 Simbol Op-Amp.

Pada dasarnya $O p$-Amp adalah sebuah differential amplifier (penguat diferensial), yang mana memiliki 2 input masukan yaitu input inverting ( $\mathrm{V}-$ ) dan input non - inverting $(\mathrm{V}+) . \quad O p$-Amp di dalamnya terdiri dari beberapa bagian, yang pertama adalah penguat diferensial, lalu ada tahap penguatan (gain), selanjutnya ada rangkaian penggeser level (level shifter) dan kemudian penguat akhir yang biasanya dibuat dengan penguat push - pull kelas B. Gambar 6 berikut menunjukkan diagram dari Op-Amp.

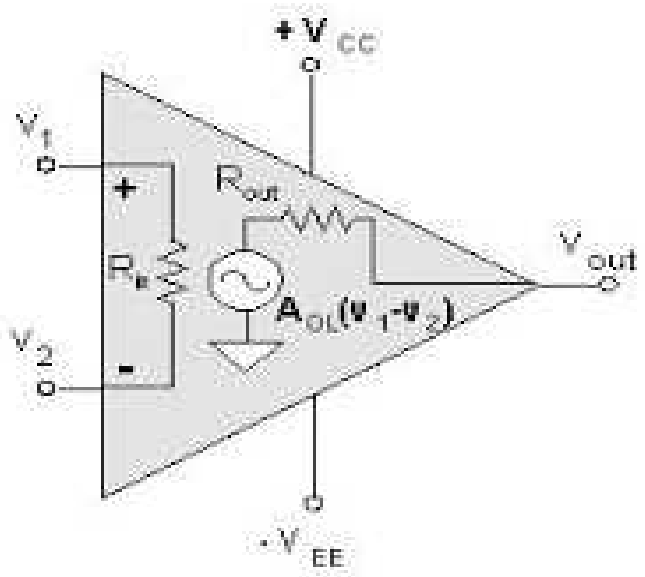

Gambar 6 Diagram Blok Op-Amp.

Fungsi dari Op-Amp adalah sebagai pengindra dan penguat sinyal masukan baik DC (Digital Converter) maupun AC (Analog Converter) juga sebagai penguat diferensiasi impedansi masukan tinggi, penguat keluaran impedansi rendah. Op-Amp banyak di manfaatkan dalam peralatan - peralatan elektronik sebagai penguat, sensor, mengeraskan suara, buffer sinyal, menguatkan sinyal, mengitegrasikan sinyal, selain itu digunakan pula dalam penguatan tegangan, filter aktif, instrumentasi, pengubahh sinyal analog ke digital dan sebaliknya. Bentuk fisik $O p-A m p$ dapat dilihat pada gambar 7 .

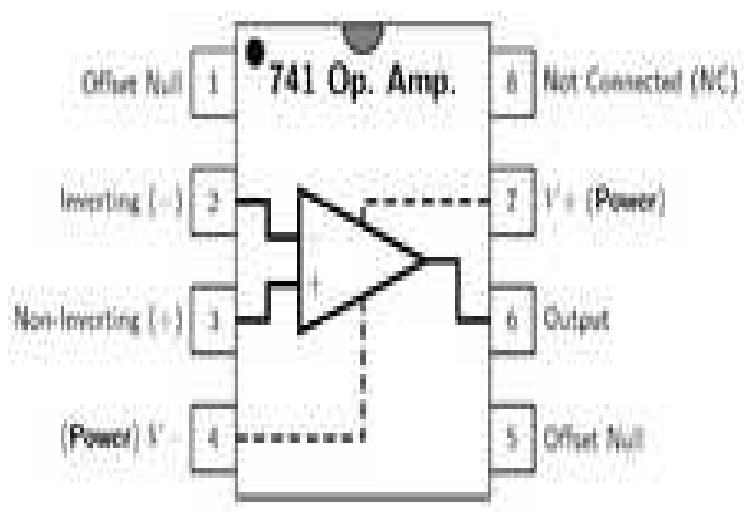

Gambar 7 Bentuk Fisik Op-Amp.

Mikrokontroler adalah rangkaian terpadu tunggal, dimana seluruh blok rangkaian yang biasa dijumpai sebagai unit-unit terpisah dapat digabung menjadi satu. 
Mikrokontroler adalah suatu chip berupa Integrated Circuit (IC) yang dapat menerima sinyal input, mengolahnya dan memberikan sinyal output sesuai dengan program yang diisikan kedalamnya. Input mikrokontroler berasal dari sensor yang merupakan informasi dari lingkungan sedangkan output ditujukan kepada aktuator yang dapat memberikan efek ke lingkungan. Jadi secara sederhana mikrokontroler dapat diibaratkan sebagai otak dari suatu perangkat / produk yang mampu berinteraksi dengan lingkungan sekitarnya. Pada perancangan simulator gelombang elektrokardiograf ini mikrokontroler yang digunakan adalah ATMega16. Mikrokontroler ini memiliki tingkat kestabilan yang lebih baik daripada mikrokontroler sejenisnya seperti ATMega 8//32, sehingga dengan menggunakan mikrokontroler ini diharapkan hasil pengukuran lebih akurat. Bentuk dari mikrokontroler ATMega 16.

Tabel 1. Analisa EKG pada Domain Waktu

\begin{tabular}{|c|c|c|}
\hline Defleksi & Deskripsi & Nilai \\
\hline $\begin{array}{c}\text { Gelombang } \\
\mathrm{P}\end{array}$ & $\begin{array}{l}\text { Gelombang EKG yang pertama } \\
\text { dilihat dengan ciri - ciri lengkung } \\
\text { kecil, defleksi positif . }\end{array}$ & Amplitudo $<0,3 \mathrm{mV}$ \\
\hline Interval PR & $\begin{array}{l}\text { Jarak antara awal gelombang P } \\
\text { dengan awal kompleks QRS, } \\
\text { pengukuran waktu antara } \\
\text { gelombang depolarisasi dari atrium } \\
\text { ke ventrikel. }\end{array}$ & Durasi $0,12-0,2$ detik \\
\hline $\begin{array}{c}\text { Interval } \\
\text { QRS }\end{array}$ & $\begin{array}{l}\text { - Gelombang Q: defleksi negatif } \\
\text { - Gelombang R: defleksi positif } \\
\text { - Gelombang S: defleksi negatif }\end{array}$ & $\begin{array}{l}\text { - Amplitudo } 25 \% \text { dari gelombang } \mathrm{R} \\
\text { amplitudo } 25 \% \text { dari gelombang } \mathrm{R} \\
\text { - Amplitudo } 1,6-3 \mathrm{mV} \\
\text { - Amplitudo } 0,1-0,5 \mathrm{mV} \text { setelah } \\
\text { gelombang } \mathrm{R} \text {. }\end{array}$ \\
\hline Segmen ST & $\begin{array}{l}\text { Jarak antara gelombang } \mathrm{S} \text { dan awal } \\
\text { gelombang T; Pengukuran waktu } \\
\text { anatara depolarisasi ventrikel dan } \\
\text { awal repolarisasi ventrikel }\end{array}$ & Durasi $0,05-0,15$ detik. \\
\hline $\begin{array}{l}\text { Gelombang } \\
\mathrm{T}\end{array}$ & $\begin{array}{l}\text { Lengkung positif setelah kompleks } \\
\text { QRS yang memrepresentasikan } \\
\text { repolarisasi ventrikel. }\end{array}$ & Amplitudo $0,1-0,5 \mathrm{mV}$ \\
\hline Interval QT & $\begin{array}{l}\text { Pengukuran waktu dari awal QRS } \\
\text { sampai akhir gelombang T yang } \\
\text { merepresentasikan aktivitas. }\end{array}$ & $\begin{array}{c}\text { Ventrikel yang berdurasi } 0,35-0,44 \\
\text { detik. }\end{array}$ \\
\hline
\end{tabular}




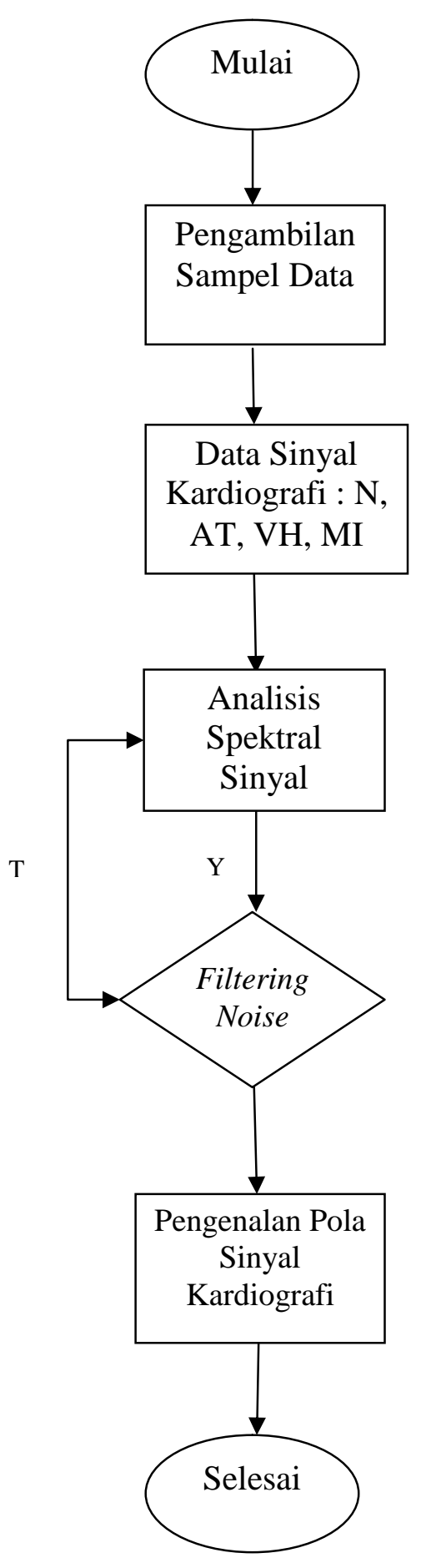

Gambar 8. Kerangka Konsep Penelitian.

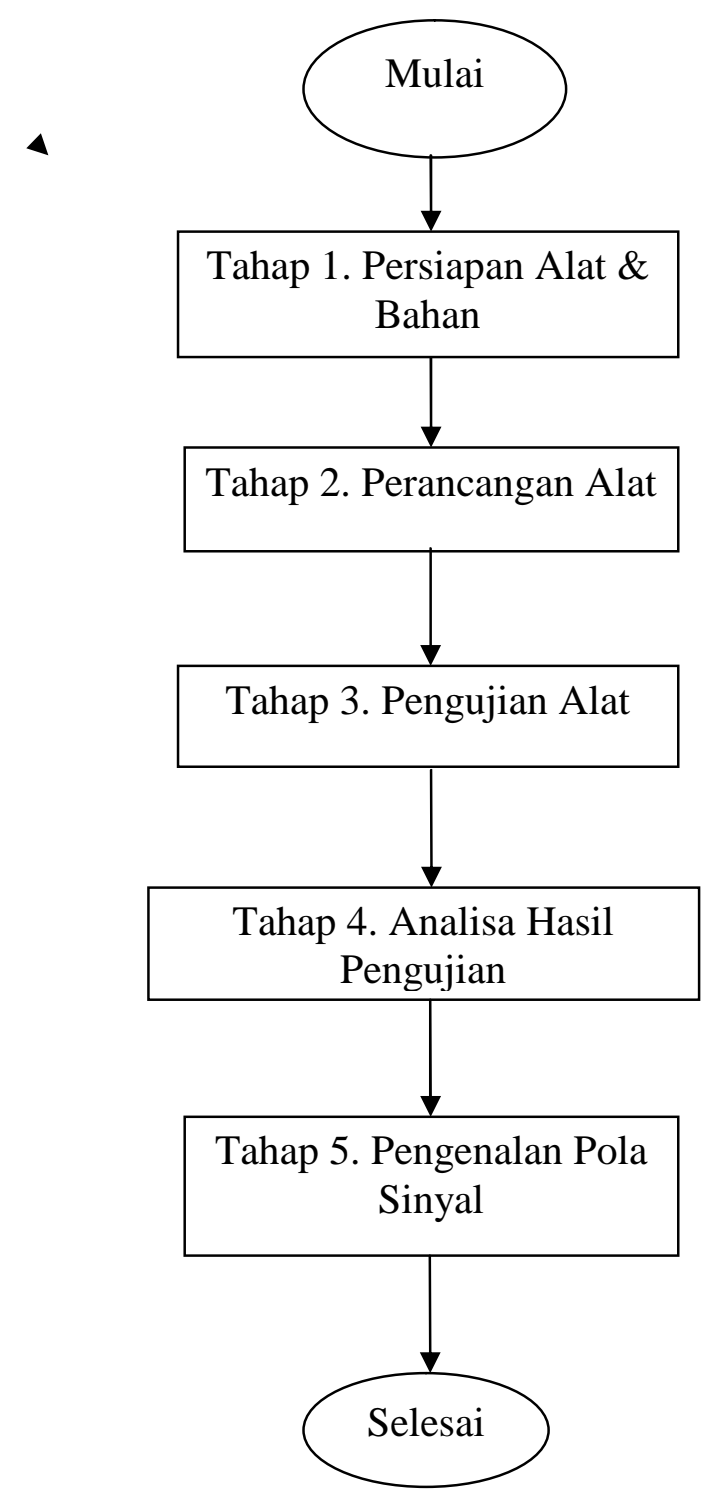

Gambar 9. Kerangka Konsep Perancangan.

\subsection{Perancangan Perangkat Keras (Hardware)}

4.5.1. Perancangan Rangkaian Power Supply

Rangkaian power supply ini berfungsi untuk memberikan tegangan ke seluruh rangkaian pada alat simulator gelombang elektrokardiograf sesuai dengan yang dibutuhkan oleh masing-masing rangkaian. Rangkaian Power Supply ini menghasilkan keluaran9 V DC dan 5 V DC. Perancangan rangkaian power supply dapat dilihat pada gambar 10. 


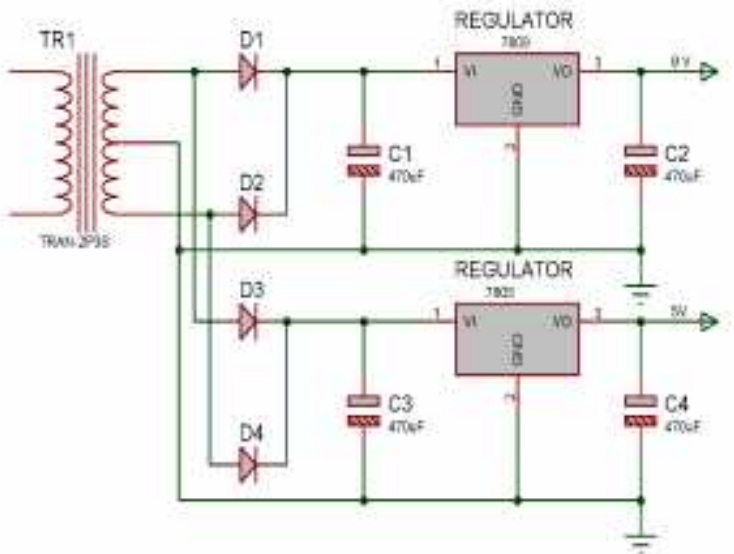

Gambar 10. Rangkaian Power Supply.

Tegangan pada trafo sebesar $220 \mathrm{~V}$ AC yang kemudian diturunkan menjadi $9 \mathrm{~V}$ AC dan $6 \mathrm{~V}$ AC, tegangan $9 \mathrm{~V}$ AC ditetapkan menjadi tegangan $9 \mathrm{~V}$ DC sedangkan tegangan $6 \mathrm{~V}$ AC diberi penyearah dioda 1 Ampere untuk menghasilkan tegangan $6 \mathrm{~V}$ DC yang kemudian oleh regulator 7805 diubah menjadi tegangan keluaran $5 \mathrm{~V}$ DC.

\subsubsection{Perancangan Rangkaian Potensiometer}

Rangkaian potensiometer berfungsi sebagai pengontrol sinyal $\mathrm{P}, \mathrm{Q}, \mathrm{R}, \mathrm{S}$ dan $\mathrm{T}$. Rangkaian potensiometer ini menghasilkan bentuk sinyal sebagai inputan pada rangkaian mikrokontroler yang kemudian diproses untuk dapat ditampilkan bagaimana bentuk gelombang sinyalnya. Perancangan rangkaian potensiometer dapat dilihat pada gambar 11.

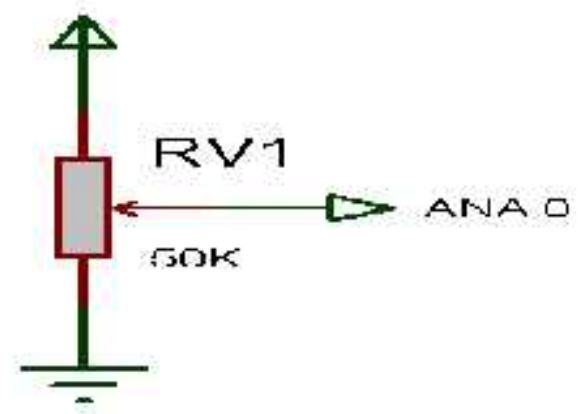

Gambar 11. Rangkaian Potensiometer.

\subsubsection{Perancangan Mikrokontroler ATmega 16}

Mikrokontroler pada perancangan alat simulator gelombang elektrokardiograf ini mengatur jalannya proses simulasi sinyal $\mathrm{P}$, $\mathrm{Q}, \mathrm{R}, \mathrm{S}$ dan $\mathrm{T}$ yang merupakan input dari rangkaian masukan (potensio), agar dapat menghasilkan output berupa nilai digital. Mikrokontroler ATmega 16 akan memperoleh masukan dan keluaran yang ada pada peralatan ini, pengontrolan tersebut dilakukan melalui pengaktifan masing masing pin pada kaki mikrokontroler tersebut, baik pengaktifan secara paralel ataupun secara per-bit mikrokontroler dalam setiap port-nya. Pada port A0-A7 merupakan input dari potensio, port $\mathrm{C} 0-\mathrm{C} 7$ dan port $\mathrm{D} 6-$ D7 digunakan untuk port data masukan LCD, sedangkan port B0-B7 dan port D0D3 untuk rangkaian DAC. Proses perancangan mikrokontroler untuk alat ini dapat dilihat pada gambar 12 .

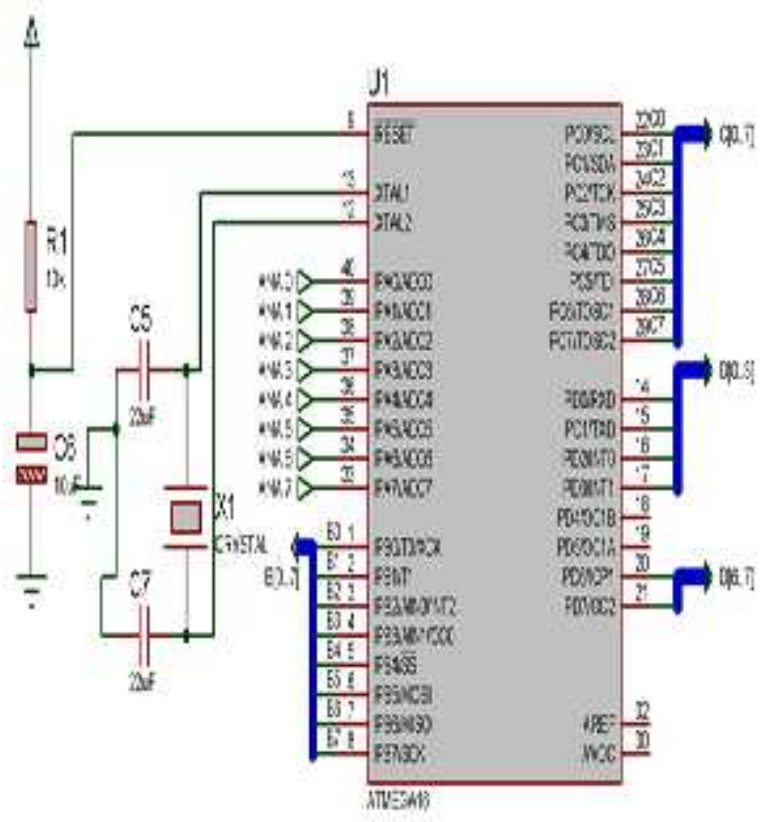

Gambar 12. Rangkaian Mikrokontroler ATmega 16.

\subsubsection{Perancangan Rangkaian Digital Analog Converter (DAC)}

Rangkaian DAC ini berfungsi sebagai pengubah sinyal digital yang didapat dari mikrokontroler menjadi sinyal analog, DAC dapat membagi tegangan yang akan menghasilkan tegangan yang bervariasi agar dapat membentuk sinyal listrik. Keluaran dari DAC akan dikuatkan oleh Operational Amplifier (Op-Amp). Perancangan rangkaian DAC dapat dilihat pada gambar 13. 


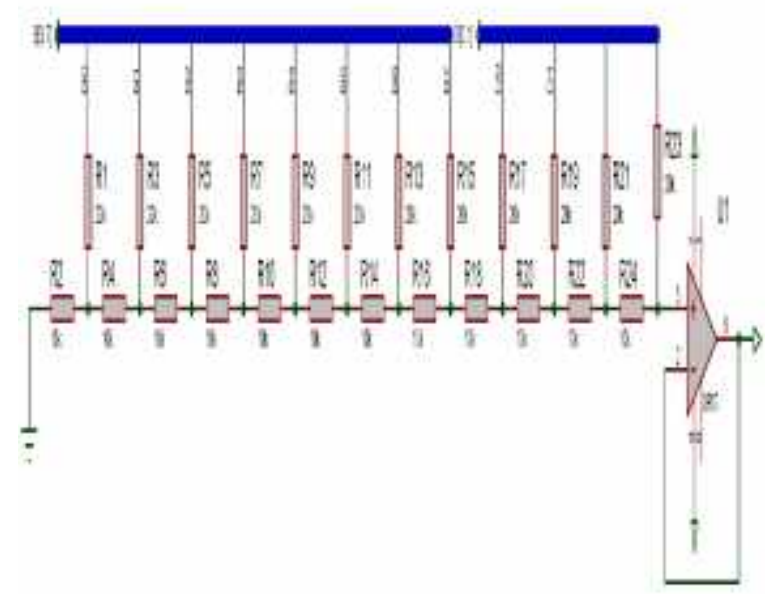

Gambar 13. Rangkaian DAC.

\subsubsection{Perancangan Rangkaian Liquid Crystal Display (LCD)}

Rangkaian Liquid Crystal Display (LCD) merupakan sebuah rangkaian yang digunakan dalam perancangan alat simulator gelombang elektrokardiograf sebagai penampil nilai gelombang sinyal $\mathrm{P}, \mathrm{Q}, \mathrm{R}, \mathrm{S}$ dan T. Perancangan rangkaian LCD dapat dilihat pada gambar 14 .

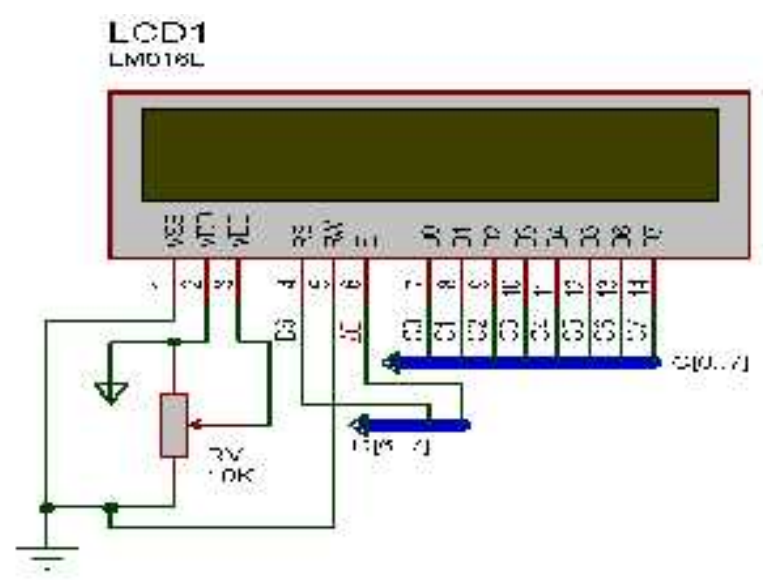

Gambar 14. Rangkaian LCD.

\subsection{Pengujian Alat}

Pengujian power supply ini dilakukan untuk mengetahui tegangan yang diperlukan oleh komponen - komponen pada alat simulasi gelombang EKG. Pada alat ini membutuhkan tegangan $5 \mathrm{~V}$ DC simetris $9 \mathrm{~V}$ DC, dimana PSA tersebut akan memberikan tegangan pada komponen - komponen yang membutuhkan tegangan tersebut. Proses pengujian rangkaian power supply dapat dilihat pada gambar 15 .

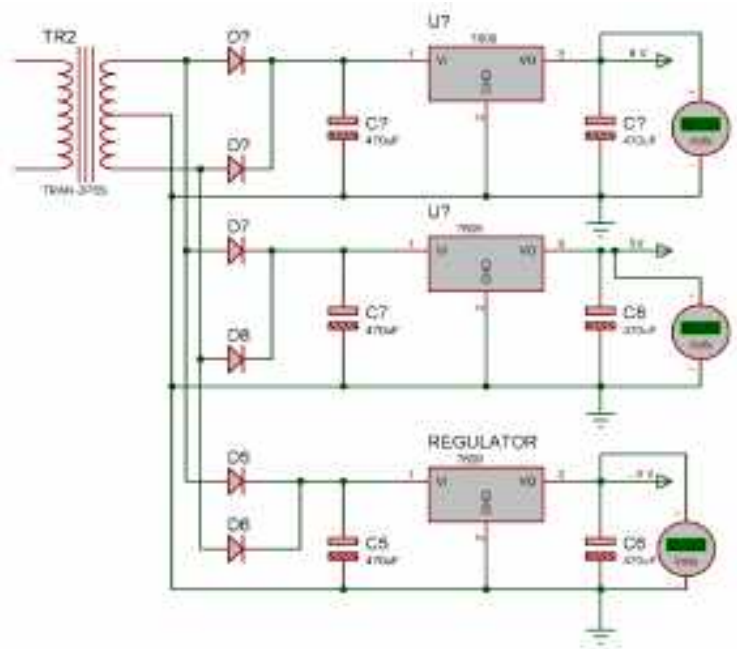

Gambar 15. Pengujian Rangkaian Power Supply.

Setelah melakukan pengujian rangkaian PSA didapatkan hasil pengukuran tegangan output regulator 7805 diperoleh keluaran rata - rata 5,15 Volt, pada pengukuran tegangan output regulator 7809 diperoleh keluaran rata - rata sebesar 9,04 Volt, sedangkan pada pengukuran tegangan output regulator 7909 diperoleh keluaran rata - rata $-8,99$ Volt. Dari hasil pengujian dapat disimpulkan bahwa rangkaian PSA berfungsi dengan baik.

\subsection{Pengujian Rangkaian Potensiometer}

Pengujian potensiometer ini dilakukan untuk mengetahui tegangan variabel dari potensio tersebut. Pengujian potensiometer ini dilakukan pada saat alat dalam kondisi $\mathrm{ON}$, dimana pada saat diputar kekiri nilainya 0 dan pada saat diputar kekanan nilainya $5 \mathrm{~V}$.

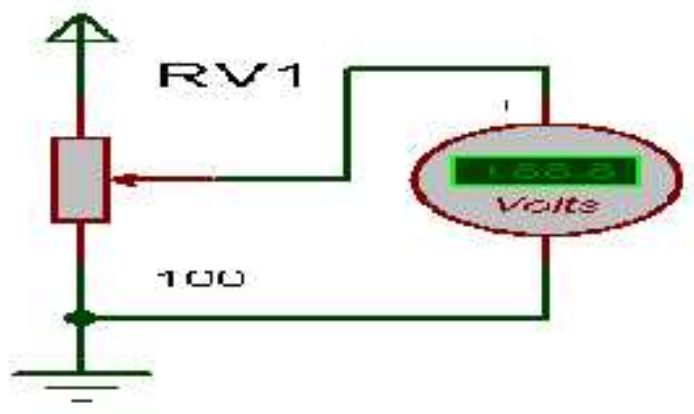

Gambar 16. Pengujian Rangkaian Potensiometer. 
Setelah melakukan pengujian rangkaian potensiometer didapatkan hasil seperti yang ditunjukan pada tabel 3. Pada saat melakukan pengukuran tegangan minimal diperoleh keluaran rata - rata 0 Volt, sedangkan pada pengukuran keluaran tegangan maksimal potensiometer diperoleh keluaran rata - rata sebesar 5,17 Volt. Dari hasil pengujian dapat disimpulkan bahwa potensiometer berfungsi dengan baik.

Tabel 3 Hasil Pengujian Potensiometer

\begin{tabular}{|l|c|c|c|c|}
\hline \multirow{2}{*}{$\begin{array}{c}\text { Kondisi } \\
\text { Potensio }\end{array}$} & \multicolumn{3}{|c|}{$\begin{array}{c}\text { Pengukuran } \\
\text { (Volt) }\end{array}$} & \multirow{2}{*}{$\begin{array}{c}\text { Rata -rata } \\
\text { (Volt) }\end{array}$} \\
\cline { 2 - 4 } & I & II & III & \\
\hline Minimal & 0 & 0 & 0 & 0 \\
Maksimal & 5,03 & 5,21 & 5,29 & 5,17 \\
\hline
\end{tabular}

\subsection{Pengujian Fungsi Alat}

Dalam melakukan pengujian sinyal, dilakukan pengujian langsung terhadap alat dan osiloskop untuk mengetahui bentuk sinyal awal. Setelah melakukan pengujian fungsi didapatkan hasil seperti yang ditunjukan pada tabel 4.

Tabel 4. Bentuk Tampilan Simulator Alat EKG

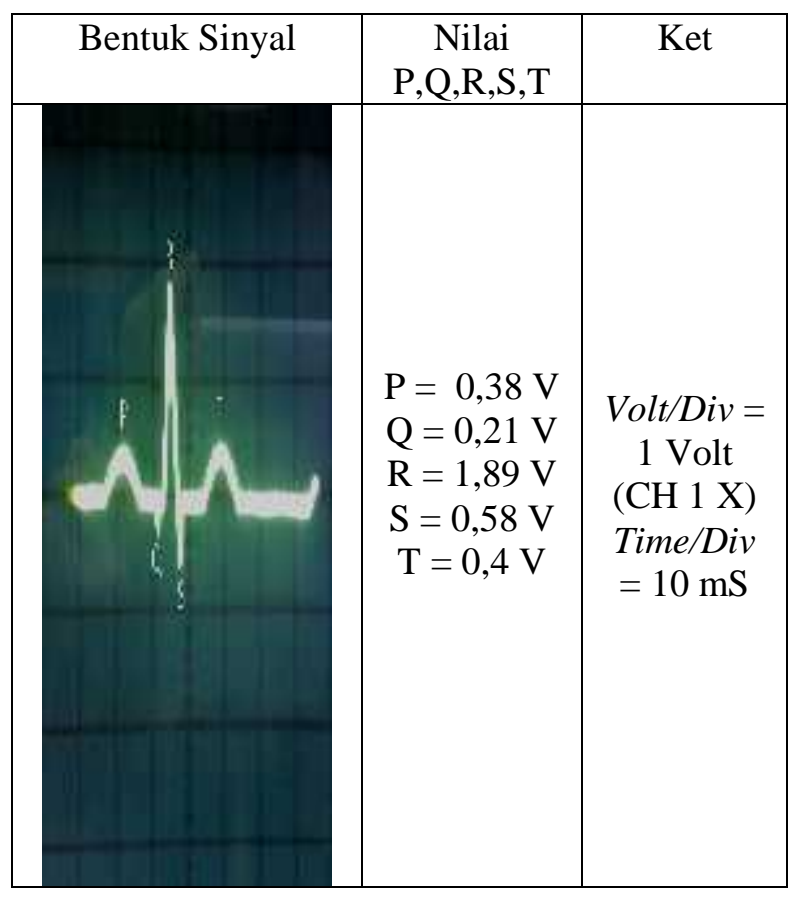

Tabel 5. Hasil Analisa Simulator EKG

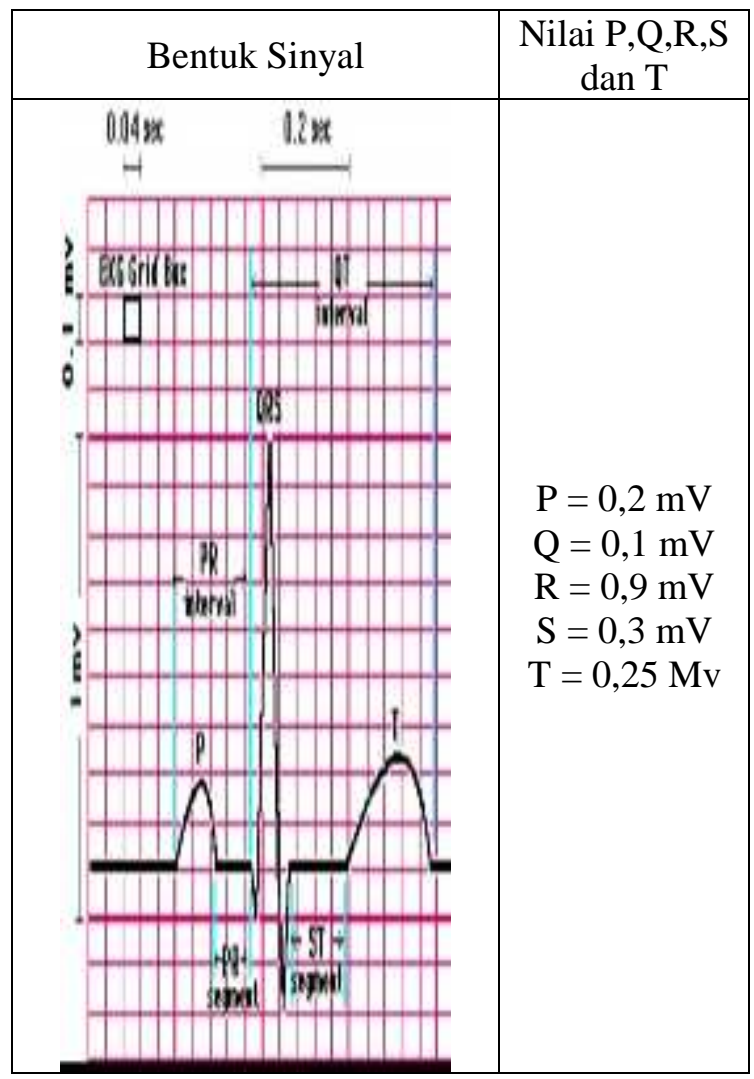

Pada tabel 5 menunjukkan nilai gelombang $\mathrm{P}, \mathrm{Q}, \mathrm{R}, \mathrm{S}$ dan $\mathrm{T}$ dengan nilai diatas yaitu dalam kondisi jantung normal pada hasil pemeriksaan EKG sebanding dengan $\mathrm{P}, \mathrm{Q}, \mathrm{R}, \mathrm{S}$ dan $\mathrm{T}$ pada tabel 4 yang merupakan hasil pengujian alat. Bentuk sinyal pada Tabel 4 puncak $\mathrm{R}$ ke puncak $\mathrm{S}$ bernilai 2,2 $\mathrm{V}$, nilai perkotaknya $1 \mathrm{~V}$ dan nilai per stripnya $0,18 \mathrm{~V}$ sebanding dengan puncak $\mathrm{R}$ ke puncak $S$ pada tabel 4 dan tabel 5 yang bernilai $1,2 \mathrm{mV}$, nilai perkotaknya $0,5 \mathrm{mV}$ dan nilai per stripnya $0,1 \mathrm{mV}$.

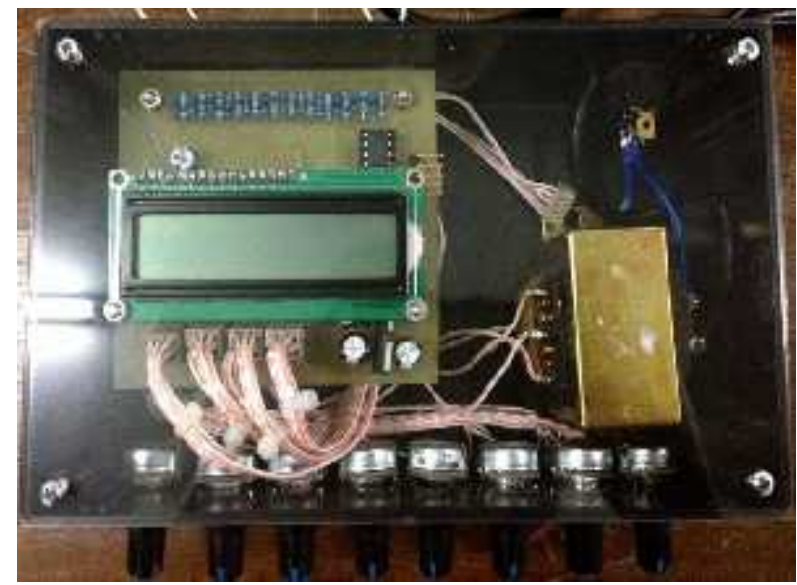

Gambar 17. Realisasi Alat Simulator. 


\section{KESIMPULAN \& SARAN}

\subsection{Kesimpulan}

a) Pada proses pengolahan sinyal kardiografi dalam arah vertikal maupun arah horisontal dapat dideteksi menggunakan lead yang terpasang pada pasien. Dengan metode ini data sinyal dapat ditentukan dalam kawasan frekuensi dan waktu.

b) Validitas sinyal hasil pemfilteran dapat diatur secara tepat dengan mengatur besarnya frekuensi pada saat melakukan pemfilteran. Pada spektrum pada dilihat hasil pengolahan sinyal yang lebih akurat. Sehingga nilai yang diharapkan sesuai dengan informasi dari pasien.

c) Dalam proses prancangan alat dengan menggunakan alat bantu osiloskop dibutuhkan beberapa rangkaian diantara power supply, pontensiometer, amplifier dan penamping LCD. Serta beberapa rangkaian pendukung lainnya. Dengan melakukan proses pembatasan data sinyal yang telah ditentlkan sesuai hasil pengolahan sinyal kardiografi sesungguhnya.

d) Berdasarkan hasil pengujian fungsi didapatkan hasil nilai $\mathrm{P}=0,38 \mathrm{~V}$ gelombang amplitudonya naik $0,40 \mathrm{~V}$ keatas, nilai $\mathrm{Q}=0,21 \mathrm{~V}$ gelombang amplitudonya turun $0,2 \mathrm{~V}$ ke bawah, nilai $\mathrm{R}=1,89 \quad \mathrm{~V}$ gelombang amplitudonya naik $1,8 \mathrm{~V}$ keatas, nilai $\mathrm{S}=$ $0,58 \mathrm{~V}$ gelombang amplitudonya turun $0,6 \mathrm{~V}$ kebawah dan nilai $\mathrm{T}=0,4 \mathrm{~V}$ gelombang amplitudonya naik 0,45 keatas.

\subsection{Saran}

a) Pengolahan sinyal belum sempurna perlu diujicoba dengan beberapa metode. Sehingga dapat diperoleh nilai yang tingkat akurasinya jauh lebih baik dan mendekati sempurna.

b) Program Matlab ini sangat membantu dalam melakukan pengolahan sinyal baik dengan metode wavelet maupun dengan metode lainnya. Dengan adanya program tersebut maka kita dapat mengolah sinyal dengan beberapa metode selanjutnya hasilnya dapat dibandingkan.

c) Alat simulator masih bisa dikembangkan lagi dengan menggunakan lead - lead yang langsung ditempelkan kepada pasien.

\section{Ucapan Terima Kasih}

Penulis mengucapkan terima kasih kepada Universitas Respati Yogyakarta yang telah memberi dukungan financial terhadap penelitian ini. Terima kasih kami sampaikan pula kepada Dr. Yeny Sulistyowati, SKM, M.Si.Med selaku kepala P3M, Sri Hasta Mulyani, S.Kom,M.Kom selaku Dekan Fakultas Sains \& Teknologi, dan segenap rekan sejawat di Universitas Respati Yogyakarta yang telah membantu dalam proses penyelesaian penelitian ini. 


\section{DAFTAR PUSTAKA}

Aminullah Dr, Elektrokardiogram, Januari 2014, AMINCIA, 2014.

Halomoan, J, Juni 2013, Analisa Sinyal EKG dengan Metode HRV (Heart Rate Variability) pada Domain Waktu Aktivitas Berdiri dan Terlentang, Seminar Nasional Aplikasi Teknologi Informasi (SNATI), Institut Teknologi Telkom, Bandung, Indonesia.

Hariati, Nurdin W.B, Identifikasi Karakter Temporan dan Potensial Listrik Statis dari Kompleks QRS dan Segmen ST Elektrokardiogram (EKG) Pada Penderita dengan Kelainan Jantung Hipertrofi Ventrikel Kiri, Universitas Hasanuddin.

Hendriyawan, MS, Implementasi Algoritma Pendeteksian Gelombang QRS komplek pada Sistem Peringatan Kelainan Kerja Jantung Berbasis Mikrikontroler, Universitas Teknologi Yogyakarta, 2012.

Rao, R. M., Bopardikar,A.Sx, Wavelet Transform: Introduction to Theory and Application, Addision-Wesley, Massachusetts, 2012.

Rizal, Ax, Pengenalan Signal EKG Menggunakan Dekomposisi Paket Wavelet dan K-Means Clustering, SNATI Yogyakarta, 2012.

S. Grace Chang, September, Adaptive Wavelet Thresholding for Image Denoising and Compression, Student Member, IEEE, University of California, 2003.
Sofia C. OLHEDE and Andrew T. WALDEN November 2003, 'Analytic' Wavelet Thresholding, Department of Mathematics, Imperial College London, SW7 2AZ, London, 2003.

Utari, Pengenalan Pola Sinyal Kardiografi dengan menggunakan Alih Ragam Gelombang Singkat, Simposium RAPI XIII Universitas Muhammadiyah Malang, 2014.

Utari, Analisa Deteksi Gelombang QRS untuk menentukan kelainan fungsi Kerja Jantung, Jurnal Teknoin Vol.22 No.1 Maret 2016 Fakultas Teknologi Industri, Universitas Islam Indonesia, 2016.

Yasak, Abdul., Arifin. A., May, Ekstraksi Parameter Temporal Sinyal ECG menggunakan Difference Operation Method, The $13^{\text {th }}$ Seminar on Intelligent Technologyand Its Applications, Institus Teknologi Sepuluh November, Surabaya, Indonesia, 2012. 